\title{
MODIFIED MUD BRICKS FOR STRENGTHENING HISTORIC EARTHEN STRUCTURES: TOWARDS SUSTAINABLE AND GREEN RESTORATION
}

\section{Mohamed M. Abdelmegeed}

\author{
Faculty of Archaeology, Fayoum University, Egypt
}

mmm04@fayoum.edu.eg

\begin{abstract}
The use of mud brick as an ancient building material reaches far back in the history of architecture. Mud bricks consist of clay and, sand, reinforced with plant fibers such as rice husks or straw. Mud bricks in most heritage buildings made of earth have suffered significant damage due to various causes. The present research aims thus at maintaining the stability, the compatibility and the compressive strength of mud bricks without changing their historical characteristics. We verify the strengthening effectiveness and their compatibility to usage when applied on mud bricks. The experimental aspect of the research included the assessment of the physical, chemical, and mechanical properties of historical mud bricks and the identification of phenomena of internal deterioration. Furthermore, the paper proposes the use of nano- and waste- reinforced mud bricks in restorations processes of historical buildings. These have been tested using different innovative mixtures such as nano-kaolin, silica fume, and Homra (fired bricks' dust), to increase the stability and durability of these mud bricks. All proposed mixtures were tested after 28 days of samples formation. The properties of proposed mixtures for mud bricks gave satisfying and promising results for the use of nano- and waste-reinforced mud bricks in the strengthening and the reconstruction of historic earthen structures. In addition, mud bricks consisting of mud, straw, fine sifted sand, homra (fired bricks' dust) provide a sustainable and green solution to restore historic earthen structures.
\end{abstract}

$$
\begin{aligned}
& \text { الملخص } \\
& \text { يعود استخدام الطوب اللبن كواد بناء قديمة إلى زمن بعيد في تاريخ }
\end{aligned}
$$

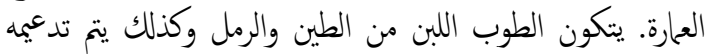

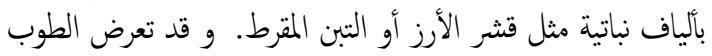

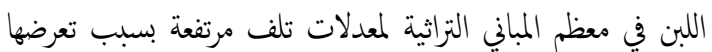

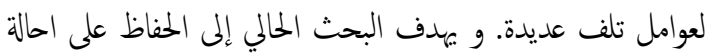

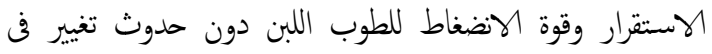

$$
\begin{aligned}
& \text { خصائصه الناريخية. و وهيدف البحث المى التحقق من فعالية التقوية }
\end{aligned}
$$

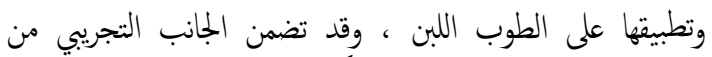

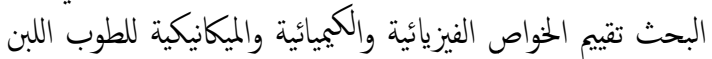

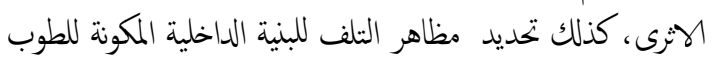

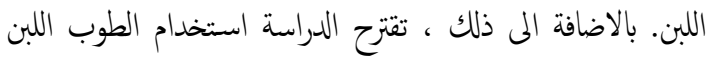

$$
\begin{aligned}
& \text { المقوى باستخدام المواد النانوية والبقايا في عمليات ترميم المباني } \\
& \text { التاريخية. وقد تم اختبار هذه المواد باستخدام مخاليط مبتكرة مختلفة }
\end{aligned}
$$

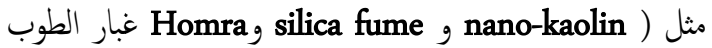

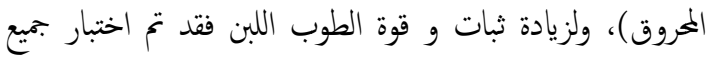

$$
\begin{aligned}
& \text { الخلطات المقترحة بعد } 28 \text { يومًا من نكوين العينات. وقد ألعات أعطت }
\end{aligned}
$$

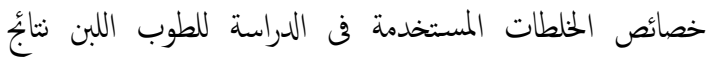

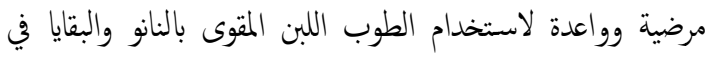

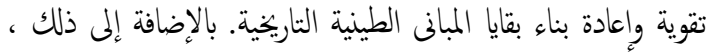

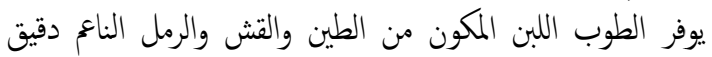

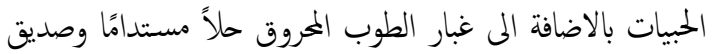

$$
\begin{aligned}
& \text { للبيئة لتزميم المبانى الطينية التاريخية. }
\end{aligned}
$$

KEYWORDS

Building materials; Strengthening;

Nanomaterials; Waste materials; Homra; Nanokaolin; Mud brick structures. 


\section{INTRODUCTION}

Mud bricks have been used for building construction for thousands of years around the world, especially in hot dry desertic climates, as seen in the most of Arabian and other desert countries. ${ }^{123}$ In Egypt, the use of mud bricks in construction dates to the Pharaonic era. Inscriptions and wall paintings in historic structures show the process of mud brick industry (Fig. 1), indicating its importance. The fabrication of mud bricks was a common and traditional

industry in Egypt whether in the Nile valley, where mud extracted from Nile deposits was used, or even in desertic locations, where the desert clay was the main raw material. ${ }^{4} 567$

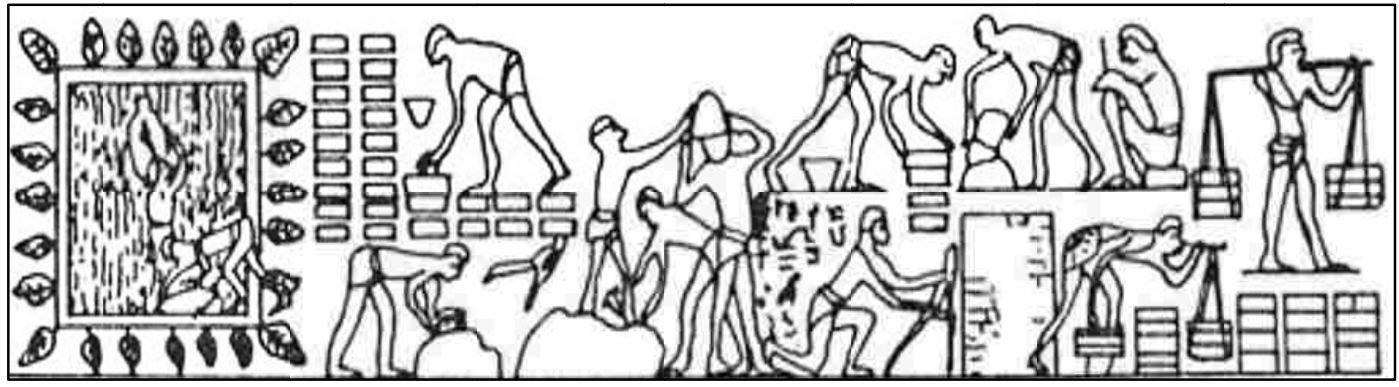

Figure 1: Brick industry in the Pharaonic age. (Ibrahim, 1987)

From an architectural and economic point of view, sun-dried mud bricks have several advantages over other masonry materials, such as fired bricks or concrete bricks. They were indeed a green building material, and involved a relatively easy manufacturing process. Skilled labor is thus not necessary. Its formation materials are natural resources, thus making it an inexpensive construction material. Furthermore, mud brick buildings perform satisfactorily under both cold and hot environmental conditions. ${ }^{8}$ However, sun-dried mud bricks also, have disadvantages, such as Their low resistance to environmental actions, as they tend to dissolve and erode under rain;

\footnotetext{
${ }^{1}$ Fathy H. "Architecture for the Poor" an Experiment in Rural Egypt, Chicago, Illinois: The University of Chicago Press, 1973.

2 Warren J. "Conservation of bricks" first edition, Butterworth Heinemann, London, England, 1999, Pp 1-6.

${ }^{3}$ Kevin D. "A field investigation of composite mud brick compressive strength" Master thesis, Department of Mechanical Engineering, Michigan Technological University, 2015, Pp. 1-3.

${ }^{4}$ Al-Ajmi F. et al "Strength behavior of mud brick in building construction" Open Journal of Civil Engineering, 2016, 6, 482-494.

${ }^{\mathbf{5}}$ Basta J. "Composition of mud brick in construction of ancient Egyptian antiquities" PhD thesis, Ain Shams University, 1991, Pp 4-18.

6 Attia A."Study of the restoration and conservation of fired bricks historic buildings, applied on one of historical Roman buildings in Tall Elfarma, South Sinai" Master Thesis, restoration Dept, Faculty of archaeology, Cairo University, 2002, Pp40- 48.

7 El-Kabbany M. "Alternative Building Materials and Components for Affordable Housing in Egypt towards Improved Competitiveness of Modern Earth Construction" Master thesis, Ain Shams University, Faculty of Engineering and University of Stuttgart, Faculty of Architecture and Urban Planning. 2013, Pp. 34-38.

${ }^{8}$ Ibrahim A. "Community participation in low income housing" Master thesis. Faculty of Engineering, Ain Shams University, 1987.
} 
shrinking and swelling of mud according to moisture ratio; and their fragile nature; not resisting earthquake hazards.

Mud brick structures are a large part of the cultural heritage worldwide, one that has to be preserved and protected. Although standards' codes, charts, documents, and guidelines contain specific indications to strengthen masonry structures, one of the key aspects for cultural heritage remains, to select strengthening procedures characterized by reversibility, high effectiveness, and low invasiveness. ${ }^{9} 101112$.

In recent years, innovative nano- and waste- materials have been developed to improve their compatibility with building materials in historic masonry buildings. ${ }^{13} 14$ 151617 . However, most of these studies refer to the strengthening of stones and mortars; others to the strengthening solutions in new building materials, very few focuses on the strengthening of ancient mud bricks with nano- and waste -materials.

For this reason, the present paper discusses on one hand, the properties of historical mud bricks and their defaults and on the other, the experimental tests made on new mud bricks strengthened by nano-materials and waste-materials. These nano- and waste-materials have been selected on their ability to resist environmental hazards.

The paper is composed of three sections. The first describes historical and modified mud bricks, the experiments and testing methods for characterizing the historical mud bricks. The second section details the physical and mechanical properties of the proposed nano-reinforced mud bricks. Finally, the experiments' results of the historical mud bricks and of the proposed nano- and waste-reinforced mud bricks are compared. Located in Kharga Oasis, El-Ghyieta temple and its mud bricks are used as the historical case study in this paper. To the west side of the Nile valley, Kharga Oasis is located about $550 \mathrm{~km}$ from Cairo. Kharga contains several Greco-Roman temples, El-Ghyieta being the most famous one and a landmark among Greco-Roman temples. El-Ghyieta temple, which was built in the Twenty-seventh dynasty, was completed during the Ptolemaic era.

\footnotetext{
${ }^{9}$ El-Kabbany M. "Alternative Building Materials and Components for Affordable Housing in Egypt towards Improved Competitiveness of Modern Earth Construction” 2013, Pp. 34-38.

${ }^{10}$ Borri A. et al" Strengthening of brick masonry arches with externally bonded steel reinforced composites" J. Compos. Constr. 2009, 13, 468-475.

${ }^{11}$ Grande E., Imbimbo M. \& Sacco E., 2011, Bond behavior of historical clay bricks strengthened with steel reinforced polymers (SRP), Materials 2011, 4, 585-600.

${ }^{12}$ El-Gohary M. "The Contrivance of new mud brick for restoring and preserving the Edfa ancient granary-Sohag, Egypt, IJCS, Vol. 3 (2), 2012.

${ }^{13}$ Hansen E., et al "A review of selected inorganic consolidants and protective treatment for porous calcareous materials" Rev. Conserv. 4 (2003) 13-25.

${ }^{14}$ Borsoi G. et al "Microstructural characterization of consolidant products for historical renders: an innovative nanostructured lime dispersion and a more traditional ethyl silicate limewater solution" Microsc. Microanal. 18 (2012) 1181-1189.

${ }^{15}$ Borsoi G. et al. "Evaluation of the effectiveness and compatibility of Nanolime consolidants with improved properties" Construction and Building Materials 142 (2017) 385-394.

${ }^{16}$ Abdelmegeed, M. et al " Innovative Composite Materials for Strengthening Lime-based Mortars in Traditional Masonry Structures, stroitel'nye materialym construction materials, 2019-773-8-42.

17 Warren J. "Conservation of bricks" first edition" 1999, p. 1-6
} 


\section{MATERIALS AND METHODS}

The experimental procedures presented in this paper were carried out to characterize the properties of historical, nano- and waste- reinforced mud bricks.

\subsection{Materials}

Two different types of mud bricks have been considered; Historical mud bricks (HMBs) and Modified mud bricks (MMBs).

- HMBs: In order to characterize the bricks' chemical, physical, and mechanical properties, four fragments or fallen bricks collected from El-Ghyieta temple were tested (Fig. 2).
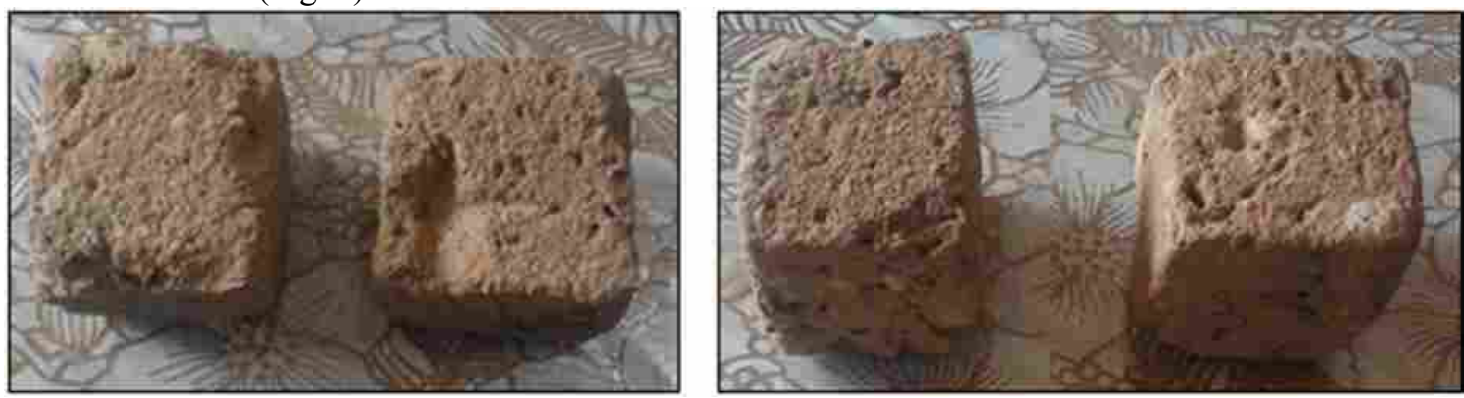

Figure 2 Historical mud bricks from El-Ghyieta temple.

- (MMBs): The materials used to produce mud brick were: sand (white and sieved sand), mud from agricultural fertile land, straw, Nanokaolina (Metakaolina Cal K, obtained by the calcination of kaolinitic clay at high temperatures $600-900^{\circ} \mathrm{C}$ ), Homra (fired brick dust), and silica fume. The raw materials and the proposed nano- and waste- materials were mixed together to reach optimum brick properties.

\subsection{Methods}

All specimens of HMBs and MMBs were tested using the following investigation methods: -

-X-Ray Diffraction (XRD) analysis: The mineralogical composition of the HMBs was determined by X-Ray Diffraction analysis using a Panalytical $X$, pert pro PW $3040 / 60, \mathrm{X}$-Ray Diffractometer, with nickel-filtered $\mathrm{Cu}$ radiation $(\lambda=1.540 \AA, 45 \mathrm{kV}$ and $40 \mathrm{~mA}$ ).

-Polarizing microscope (PM): the mineralogy, texture, shape and distribution of pores were studied by means of optical microscopy or polarizing microscope. Mineralogical investigation was done using the Polarizing Microscope (PM) Zeiss Axio Imager under both plane-polarized light (PL) and crossed

-SEM/EDX examination: The sample is investigated through Scanning Electron Microscope (SEM) to investigate the morphological features of HMBs and MMBs. A SEM at acceleration voltages of 10-30 kV was used in addition to EDX- Oxford with JSM 5300 in order to analyses the chemical components of the samples.

-Shimadzu compressive machine: in order to determine the compressive strength of HMBs and MMBs, the Shimadzu compressive machine was used on the mud brick samples. 


\section{1- Results for HMBs}

The results for the Historical mud bricks follow:

\section{1- XRD results}

Mineralogically, mud bricks are differing in its mineralogical compositions. The tested sample (Fig. 3) showed that the mud bricks used were rich with quartz $\left(100 \%\right.$ quartz, $\left.\mathrm{SiO}_{2}\right)$.

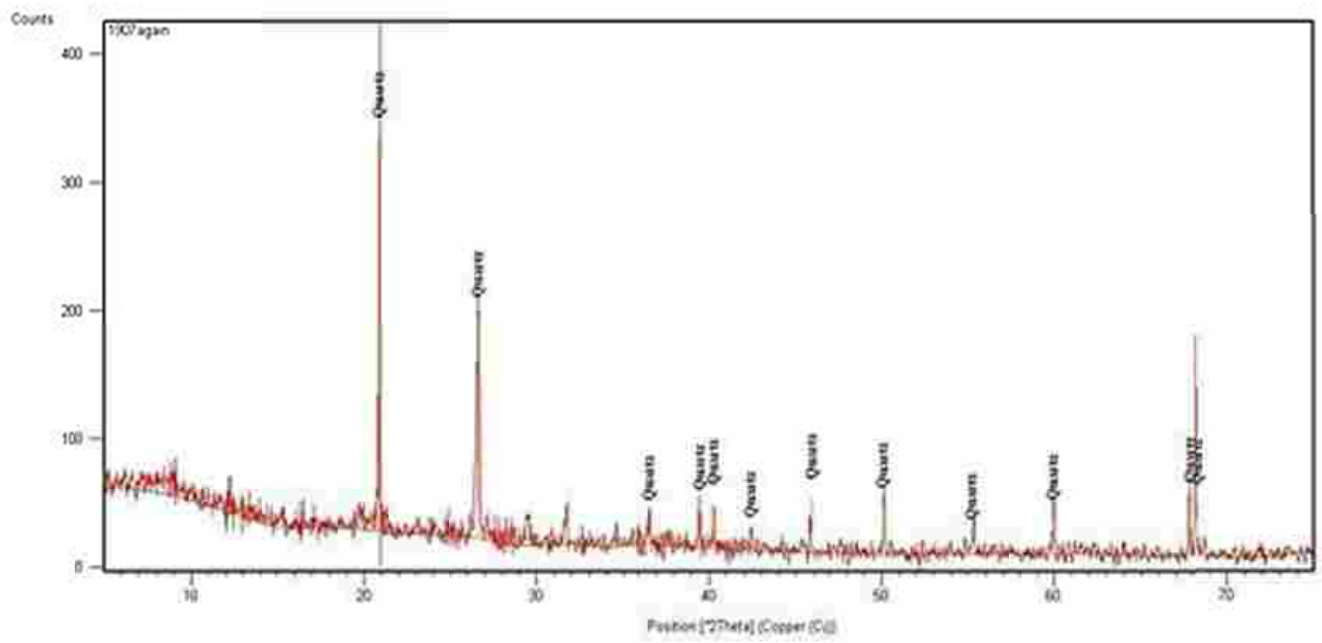

Figure 3 XRD patterns of HMBs

\section{2- SEM/EDX results}

To validate the morphological properties of the HMBs, the matrices of the two tested samples were investigated by SEM. Figs 4a \& 5a show the internal fault zones through fissures (arrows) as well as holes and cavities (circles). This is a sign that bricks characterized as low density, low compressive strength, and high porosity.

(a)
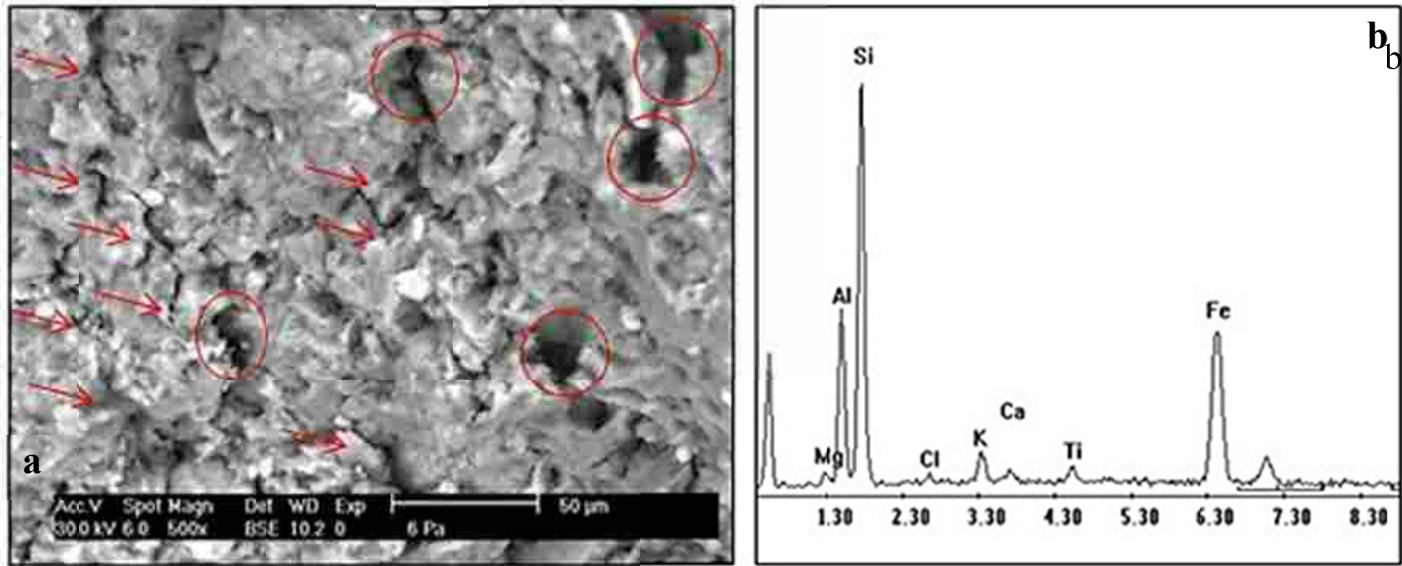

Figure 4: a) SEM micrograph and b) EDX analysis of HMBs sample No.1 
However, EDX results show the presence of deterioration product elements $(\mathrm{Mg}, \mathrm{Cl}, \mathrm{Ca}, \mathrm{Fe})$, which are responsible for deterioration features in the samples. Such elements considered as indicators of deterioration actions affecting the mud bricks. These indicate that mud bricks do not have the ability to resist deteriorating actions, due to their poor physical and mechanical properties.
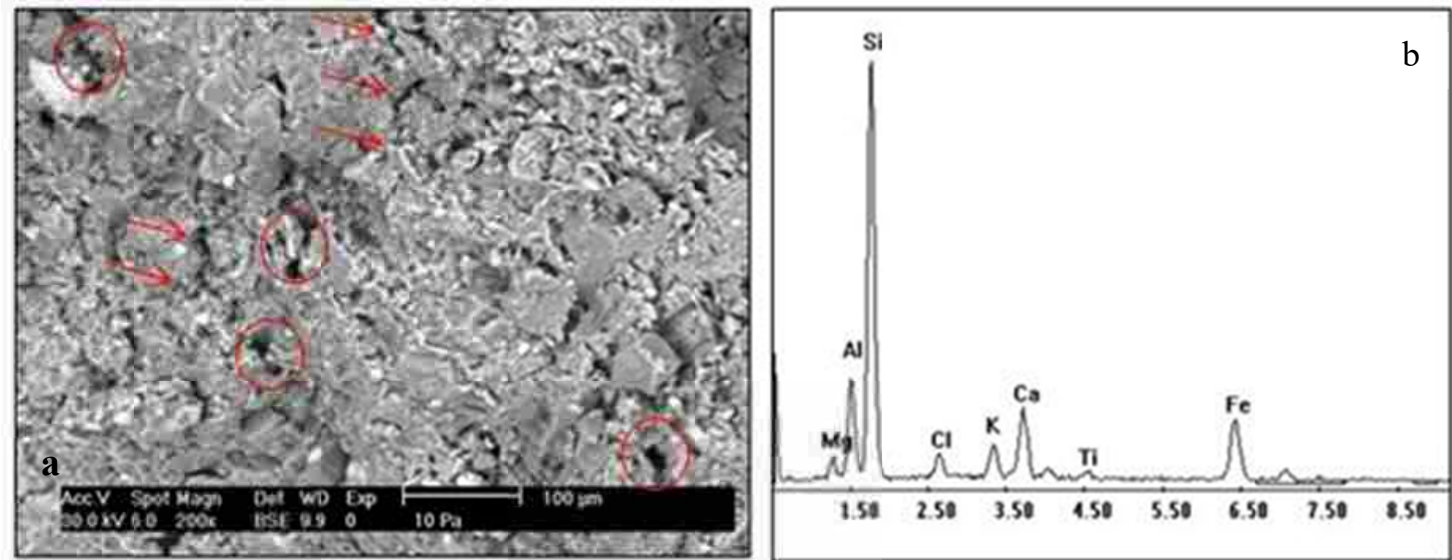

Figure 5: a) SEM micrograph and b) EDX analysis of HMBs sample No.2

\section{3- $\quad$ Thin-Section test results}

The mineralogy and texture of the two samples (No. 1 and No. 2) of HMBs were investigated with a polarizing microscope (PM). Fig. 6 presents their petrographic features. The fabric and structure of the bricks are characterized by a non-calcareous matrix of brown, dark brown, and greenish brown color. However, Fig. $6(\mathrm{a}, \mathrm{b})$ indicates the poor internal bonding between silt-dominated, strawdominated and clay- dominated layers.
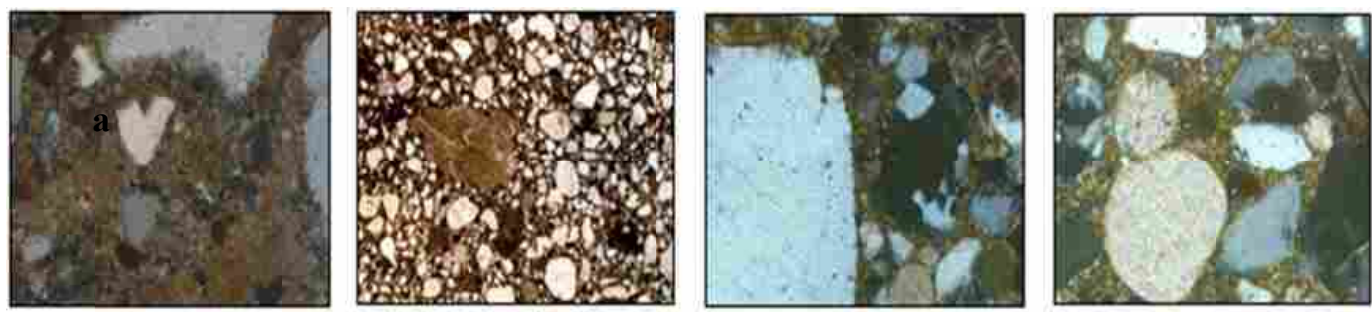

Figure 6 Photomicrographs of thin-sections of HMBs samples

\section{4- Compressive test results}

The compressive test was carried out on three cubic samples extracted from falling bricks of the Greco-Roman temple. Before performing the compressive strength tests, all samples have been dried in a thermal oven and weighed by using an electronic scale. The weight, failure load, and compressive strength results of HMBs are presented in Table 1.

Table 1: Compressive test results of HMBs

\begin{tabular}{|c|c|c|c|c|c|c|}
\hline $\begin{array}{l}\text { Sample } \\
\text { ID }\end{array}$ & Side a & $\begin{array}{l}\text { nensior } \\
(\mathrm{cm}) \\
\text { Side b }\end{array}$ & height & $\begin{array}{l}\text { Weight } \\
(\mathrm{kg})\end{array}$ & $\begin{array}{l}\text { Failure Load } \\
\qquad(\mathrm{KN})\end{array}$ & $\begin{array}{c}\text { Compressive } \\
\text { strength } \\
\left(\mathrm{kg} / \mathrm{cm}^{2}\right)\end{array}$ \\
\hline 1 & 4.90 & 5.00 & 4.80 & 0.210 & 11.53 & 48.05 \\
\hline 2 & 4.80 & 4.90 & 4.90 & 0.215 & 11.4 & 48.46 \\
\hline 3 & 4.90 & 4.80 & 4.80 & 0.198 & 10.9 & 46.34 \\
\hline
\end{tabular}




\section{2- Results for MMBs}

The overall objective of this study is to improve mud brick consolidation by using nano- and waste-materials, such as nanokaolina, silica fume, and Homra this is to increase the ability of mud bricks to resist long-standing weathering actions.

\section{1- Strengthening system}

The materials used to produce modified mud brick were mud and sand as main matrix materials, and rice straw as fibrous and temper material. The proposed strengthening materials added to the mixtures were metakaolina (nanomaterial), fly ash and Homra (waste materials). Table 2 shows the proposed mixtures of the reinforced nano- and waste-mud brick samples. All reinforced specimens have been prepared according to a standardized procedure matching the shape, color, and texture of the historical mud bricks (HMBs).

Table 2: The content and volume ratio of modified mud brick s' (MMBs) composition

\begin{tabular}{|c|c|c|c|c|c|c|}
\hline \multirow{2}{*}{$\begin{array}{l}\text { Sample } \\
\text { ID }\end{array}$} & \multicolumn{2}{|c|}{ Main matrix material } & $\begin{array}{l}\text { Fibrous } \\
\text { material }\end{array}$ & \multicolumn{3}{|c|}{ Additives materials } \\
\hline & Clay & Sand & Rice straw & Metakaolina & Fly ash & Homra \\
\hline 1 & 3 & 1 & $1 / 4$ & -------- & -------- & -------- \\
\hline 2 & 3 & 1 & $1 / 4$ & $1 / 8$ & -------- & ------- \\
\hline 3 & 3 & 1 & $1 / 4$ & ------- & $1 / 8$ & ------ \\
\hline 4 & 3 & 1 & $1 / 4$ & --------- & -------- & $1 / 8$ \\
\hline
\end{tabular}

\section{2- SEM/EDX test results}

The matrix of the four samples (samples 1, 2, 3, 4) was investigated by SEM. Figs $7 \mathrm{a}, 8 \mathrm{a}, 9 \mathrm{a}$, and 10a show the internal zones of the samples strengthened with rice straw, metakaolina, fly ash and Homra respectively. Table 3 and Figs 7b, 8b, 9b, and $10 \mathrm{~b}$ show the EDX results for the samples.

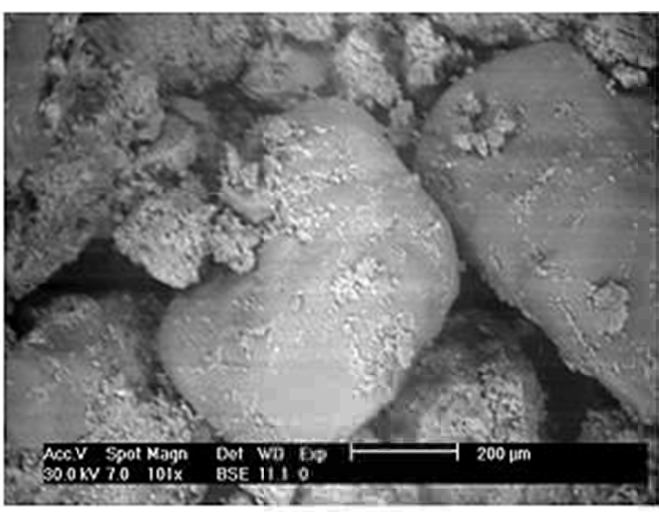

(a)

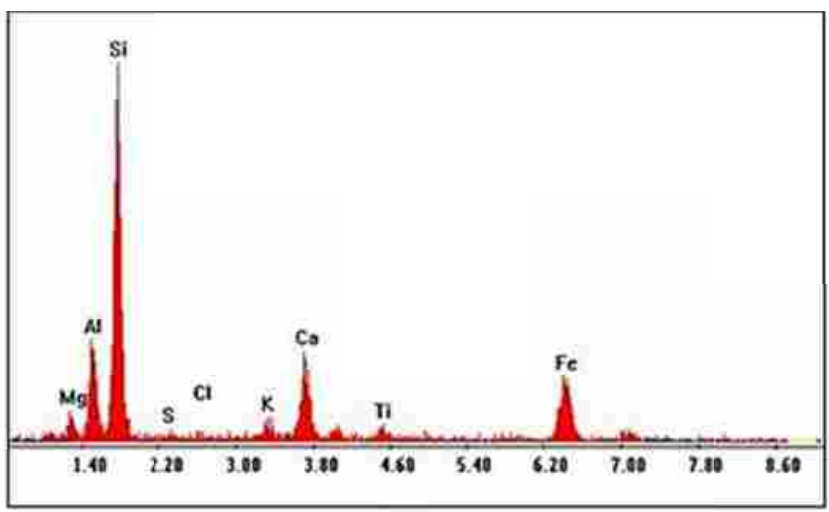

(b)

Figure 7 SEM micrograph and b) EDX analysis of MMBs sample No.1

\footnotetext{
- 269 - Modified mud bricks for strengthening historic earthen structures
} 


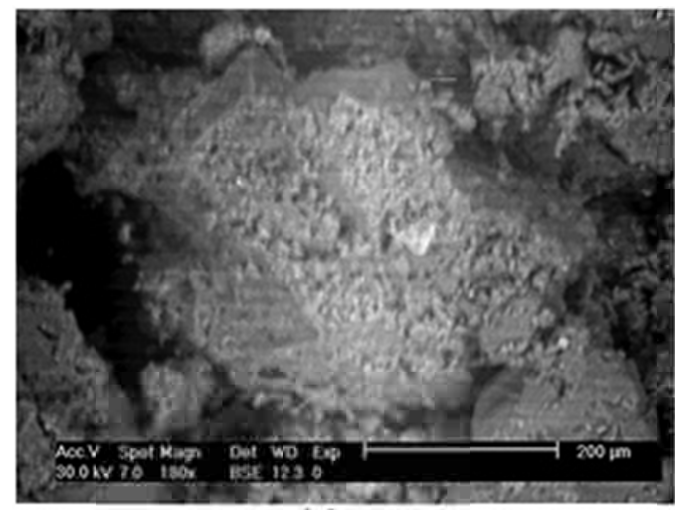

(a)

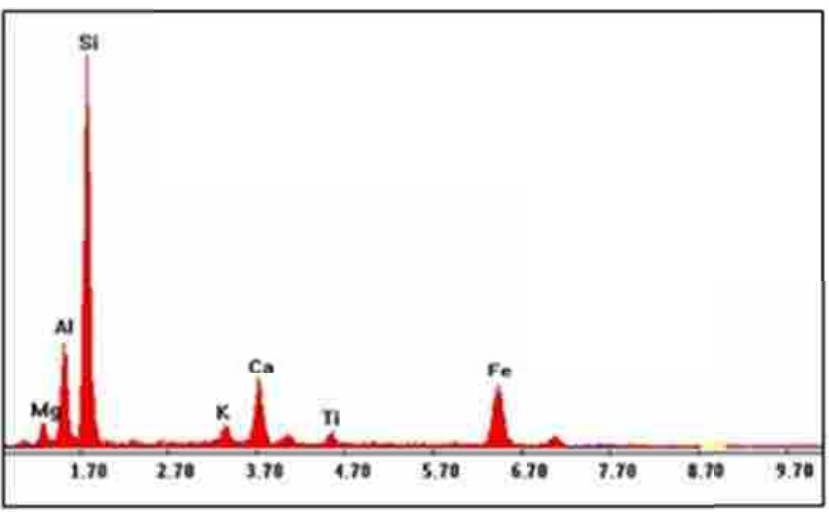

(b)

Figure 8 SEM micrograph and b) EDX analysis of MMBs sample No.2

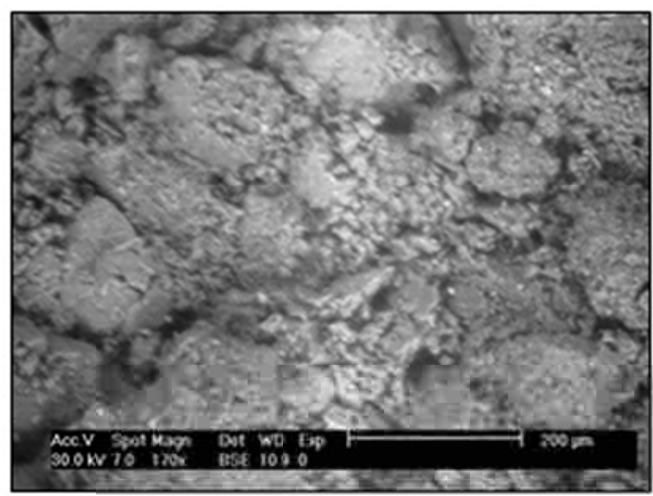

(a)

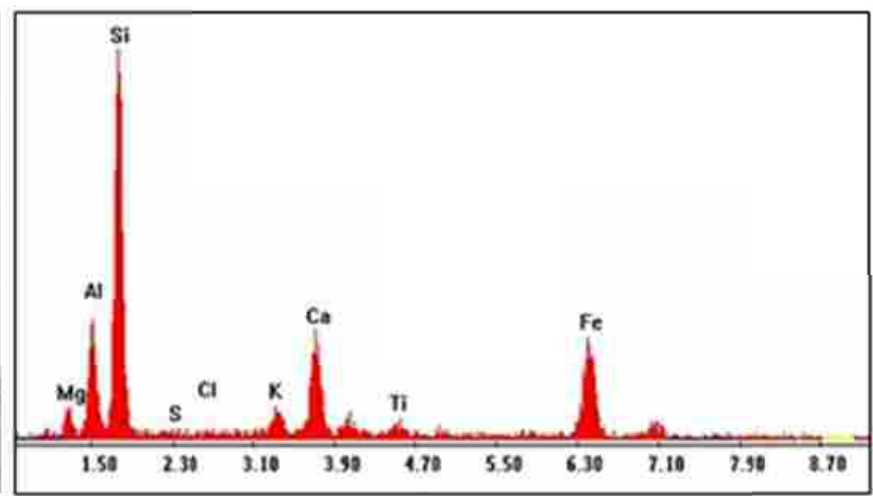

(b)

Figure 9 SEM micrograph and b) EDX analysis of MMBs sample No.3

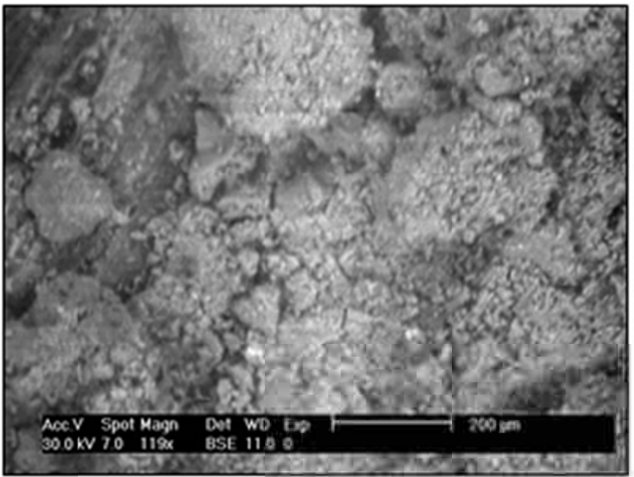

(a)

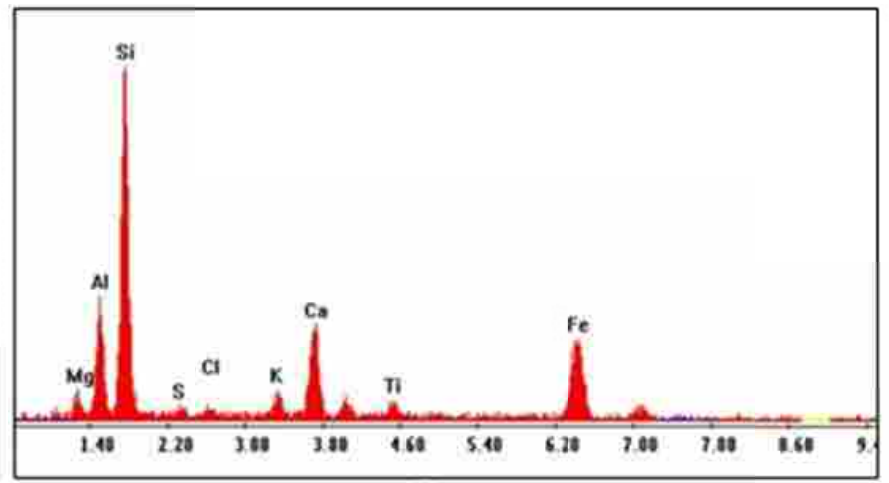

(b)

Figure 10 SEM micrograph and b) EDX analysis of MMBs sample No.4 
Table 3: Results of EDX analysis of MMBs samples

\begin{tabular}{|c|c|c|c|c|}
\hline \multirow{2}{*}{ Element } & \multicolumn{4}{|c|}{ Sample ID } \\
\cline { 2 - 5 } & $\begin{array}{c}\mathbf{1} \\
\mathbf{A t} \%)\end{array}$ & $\begin{array}{c}\mathbf{2} \\
\mathbf{A t} \%)\end{array}$ & $\begin{array}{c}\mathbf{3} \\
\text { (At \%) }\end{array}$ & $\begin{array}{c}\mathbf{4} \\
\text { (At \%) }\end{array}$ \\
\hline $\mathrm{Mg}$ & 4.72 & 3.55 & 4.75 & 4.26 \\
\hline $\mathrm{Al}$ & 15.51 & 15.55 & 16.27 & 16.33 \\
\hline $\mathrm{Si}$ & 56.00 & 60.00 & 52.00 & 50.93 \\
\hline $\mathrm{S}$ & 1.14 & ----- & 1.35 & 1.49 \\
\hline $\mathrm{Cl}$ & 0.93 & ----- & 1.23 & 1.50 \\
\hline $\mathrm{K}$ & 2.13 & 2.30 & 2.88 & 2.60 \\
\hline $\mathrm{Ca}$ & 9.05 & 7.61 & 8.59 & 9.65 \\
\hline $\mathrm{Ti}$ & 0.99 & 1.34 & 1.49 & 1.64 \\
\hline $\mathrm{Fe}$ & 9.55 & 9.65 & 11.45 & 11.59 \\
\hline
\end{tabular}

\section{3- Compressive test results}

The compressive test was carried out on samples of MMBs, after having been dried in thermal oven and weighed with an electronic scale. The weight, failure load, and compressive strength values of the MMBs are given in Table 4.

Table 4: The compression test values of MMBs

\begin{tabular}{|c|c|c|c|c|c|c|}
\hline $\begin{array}{c}\text { Sample } \\
\text { ID }\end{array}$ & Side a & $\begin{array}{c}\text { imensio } \\
\text { (cm) } \\
\text { side b }\end{array}$ & height & $\begin{array}{l}\text { Weight } \\
\text { (kg) }\end{array}$ & $\begin{array}{c}\text { Failure Load } \\
(\mathbf{k N})\end{array}$ & $\begin{array}{l}\text { Compressive } \\
\text { strength } \\
\text { (MPa) }\end{array}$ \\
\hline 1 & 5.00 & 5.00 & 4.90 & 0.198 & 12.31 & 4.92 \\
\hline 2 & 5.00 & 4.90 & 5.00 & 0.234 & 16.20 & 6.35 \\
\hline 3 & 4.90 & 4.80 & 4.90 & 0.203 & 13.50 & 5.51 \\
\hline 4 & 5.00 & 4.90 & 4.80 & 0.288 & 19.03 & 7.77 \\
\hline
\end{tabular}

\section{3- DISCUSSION AND REMARKS}

Historic mud bricks (HMBs) can be described as a composition of deposit and sediment materials, being a source of cultural knowledge, social technology, cultural information, and environmental information. ${ }^{18}{ }^{19}$ In Egypt, social practice and technology of mud bricks started since the prehistoric period. practically, the production of mud bricks varies according to available natural resources, the manufacturing process, craft specialization, and the laborer's who made it. ${ }^{21} 22232425$ . The manufacture of mud bricks is a versatile, varying considerably from one culture

\footnotetext{
${ }^{18}$ Cameron, C. "Coursed adobe architecture, style, and social boundaries in the American Southwest" In the archaeology of social boundaries, edited by Stark M., Washington Smithsonian institution press, 1998, Pp183-208.

${ }^{19}$ Emery V. "Mud-Brick" In UCLA Encyclopedia of Egyptology, edited by W. Wendrich. Los Angeles: e-Scholarship, 2009.

${ }^{20}$ Serena L. "Field Methods for the Analysis of Mud Brick Architecture" Journal of field archaeology, 2017, Vol. 42, No. 4, 351-363

${ }^{21}$ Emery V. "Mud-Brick, in UCLA Encyclopedia of Egyptology" 2009.

${ }^{22}$ Elgar G. "The devolution of mud brick: Ethno- archaeology of abandoned earthen dwellings in the Bolivian Andes." Journal of Archaeological Sciences (2008) 35: 3057-3071.

${ }^{23}$ Homsher R. "Mud bricks and the process of construction in the Middle Bronze age Southern Levant.” Bulletin of the American Schools of Oriental Research, 2012, Pp368: 1-27.

${ }^{24}$ Elgar G. et al "Geochemical characterization of Bolivian formative earthen architecture by Wavelength-Dispersive X-Ray Fluorescence." Geoarchaeology, 2015: 30(1): 32-58.

${ }^{25}$ Serena L. "Field Methods for the Analysis of Mud Brick Architecture" Journal of field archaeology, 2017, Vol. 42, No. 4, 351-363
}

- 271 - $\mid$ Modified mud bricks for strengthening historic earthen structures 
to another. HMBs production in Egypt is a traditional industry whether in the Nile valley, where mud extracted from the Nile sedimentation was used, or even in the desert communities, where the desert clay was the main casting raw material. ${ }^{26} 272829$ The most distinct stage in the manufacturing of mud bricks is the addition of dry straw in order to reduce shrinkage during drying process. Whether, rice, wheat, barley, and rye straw. HMBs as building materials has some disadvantages such as low resistance to environmental action, always tend to dissolve and erode under rain impact, shrinking and swelling of mud according to moisture ratio and it is a fragile material, that can't resist earthquake hazards. To determine the deterioration factors and phenomena in historical mud bricks, examinations and analysis were carried out. To identify the chemical and mineralogical composition of HMBs, samples were analyzed with the XRD technique. XRD test demonstrated that, the mud bricks in Greco-Roman structures were silt-rich-bricks. XRD patterns (Fig. 3) show that the examined samples contain as little as $5 \%$ clay with more than $80 \%$ sand ${ }^{30}$ reaching in some cases, $95 \%$. This high ratio of sand explains the dissolution and erosion of HMBs..

Following the XRD test, HMBs samples were investigated with a polarising microscope (PM). As shown in Fig. 6, the petrographic features of the investigated samples are characterised by a non-calcareous matrix of brown, dark brown and greenish brown colours. Fig. $6(\mathrm{a}, \mathrm{b})$ also indicates the poor internal bonding between silt-dominated, straw-dominated and clay-dominated layers. Petrographic analysis was carried out to determine the mineralogical composition and texture of HMBs samples. ${ }^{31} 3233$ The morphological description and chemical composition (SEM/EDX test) show the weak internal structure of HMBs. As shown in Figs. 4 and 5, the samples have many issues, including micro-cracks, cavities, small fissures, and eroded pits. The defaults features are due to production errors (high ratio of sand) and the absence of proper tempering agent (straw) that increases shrinking and swelling processes. Furthermore, the absence of salts minerals in the samples, in particular halite crystals which are prevalent in Egyptian soil, ${ }^{34} 3536$ are due to the low moisture

\footnotetext{
${ }^{26}$ Fathy H. "Architecture for the Poor" an Experiment in Rural Egypt, Chicago, Illinois: The University of Chicago Press, 1973

${ }^{27}$ Basta J. "Composition of mud brick in construction of ancient Egyptian antiquities" 1991, Pp. 4-18.

${ }^{28}$ Attia A."Study of the restoration and conservation of fired bricks historic buildings, applied on one of historical Roman buildings in Tall Elfarma, South Sinai" 2002, Pp40- 48.

${ }^{29}$ El-Kabbany M. "Alternative Building Materials and Components for Affordable Housing in Egypt towards Improved Competitiveness of Modern Earth Construction” 2013, Pp. 34-38.

${ }^{30}$ French C. "Sediments analysis of mud brick and natural features at El-Amarna" In Amarna Reports I, edited by B. Kemp, London: Egypt Exploration Society, 1984, Pp.189-201.

${ }^{31}$ Nodarou E. et al "Another (mud) brick in the wall: scientific analysis of Bronze Age earthen construction materials from East Crete “ Journal of Archaeological Science 35 (2008) 2997-3015

${ }^{32}$ Abdelmegeed M. et al "Assessment of physical and mechanical properties of historical and traditional masonry buildings: a case study" Iternational journal of conservation science (IJCS) Volume 5, Issue 3, July-September 2014: 343-354

${ }^{33}$ El-Gohary M. "Investigations of limestone weathering of El-tuba minaret El-Mehala, Egypt: a case study" MAA, 2010, Vol. 10 (1), pp: 61-79

${ }^{34}$ Fitzner B. "Damage diagnosis on stone monuments-weathering forms, damage categories and damage indices" in: Viles, H. \& 3Ĝikryl, R., (eds.) Understanding and managing of stone decay, Proc. of the Int. Conf. Stone Weathering and Atmospheric Pollution Network (SWAPNET 2001), Karolinum Press, Charles Univ., Prague, pp. 11-56

${ }^{35}$ El-Gohary, M. "A holistic approach to the assessment of the groundwater destructive effects on stone decay in Edfu temple using AAS, SEM-EDX and XRD” Environ- Earth. Sci., (2016) Vol. 75 (13), Pp.1-11
} 
content in the surrounding environment as the studied structure is located in a dry desert climate.

The aim of this study is to produce a modified mud bricks (MMBs) by enhancing the physical and mechanical properties of mud bricks by using nano- and waste-materials as strengthening additives. The proposed additives to the MMBs are metakaolina (nanokaolina), silica fume and Homra. The purpose of these additives is to increase the ability of mud bricks to resist weathering and deteriorating actions, as well as doing so while using green and sustainable materials in conservation and reconstruction processes of historic earthen structures. It has been suggested here to produce MMBs containing agricultural fertile clay (matrix material), white and sieved sand (filling material), and rice straw (temper material), and nanokaolina, homra and silica fume (strengthening material). The ratio of the proposed mixtures (matrix material, filling material, temper material, strengthening material) were $3: 1: 1 / 4: 1 / 8$ $(300 \%, 100 \%, 25 \%, 12.5 \%)$ respectively.

The Scanning Electron Microscope (SEM) was used to define the morphological properties of the nano- and waste-reinforced mud bricks, as well as to determine the bonds created between the nano- or waste-materials with the raw materials of mud bricks, and the treatment of the inner faults of the historical mud bricks. Figs. 7-10 show that, the MMBs do not have the inner cavities and cracks in contrast with HMBs. Therefore, the MMBs have the ability to resist better to the formation of cracks due to the shrinking process during drying time. Three types of strengthening materials, namely, rice straw (Fig. 7), metakaolina (Fig. 8), Fly ash (Fig. 9), and homra (Fig. 10) were used. The results show that, rice straw and homra are good addition to mud and sand to produce mud bricks. This mixture produces compact mud brick with high degrees of plasticity and low degree of shrinkage, and this is clear in the absence of internal cracks. The addition of rice straw and fly ash to mud and sand produces mud bricks with suitable bonds between its internal components (Fig. 9). Therefore, the use of waste materials is recommended to be a good mixture to produce a green and sustainable mud bricks.

The compressive strength of MMBs was examined to establish if the waste mixture can increase the mechanical properties of mud bricks. The three proposed mixtures, i.e. straw only, metakaolina (nano material), fly ash and homra (waste materials) were tested to identify the load capacity of the proposed MMBs. Table 4 and Fig. 11 indicate that the MMBs consisting of mud, sand, rice straw, and homra with a ratio of 3:1: $1 / 4: 1 / 8$ respectively, had an increase resistance to the compressive strength of the produced mud bricks. The proposed mud bricks show noticeable difference in the mineralogical and mechanical properties among the proposed mixture categories (straw only, metakaolina, fly ash and homra).

Finally, the study concluded that adding homra to the components of mud brick samples played an important role in increasing the compressive capacity of the produced brick. It was deemed suitable recommend using MMBs in restoration and conservation of historic earthen structures. Indeed, MMBs following the

\footnotetext{
${ }^{36}$ Abdelmegeed, M., Hassan, S. "Diagnostic investigation of decaying limestone in historical buildings at the Mamluks cemetery- city of the dead, Egypt" Egyptian Journal of Archaeological and Restoration Studies "EJARS", Volume 9, Issue 2, December - 2019: Pp. 183-196
}

- 273 - Modified mud bricks for strengthening historic earthen structures 
forementioned ratio present good mechanical and physical characteristics, in addition to their external appearance being similar to that of HMBs.

\section{4- CONCLUSION}

Nowadays, a considerable effort is done by restorers use waste and nanomaterials to cultural heritage safeguarding. Nano-materials represent one of the most efficient alternative solutions as strengthening and repair systems for earthen monuments' restoration. Waste-materials have received extensive attention for their strengthening and treatment of historical and masonry structures, including the socalled sustainable and green restorations.

In this study the results of physical and mechanical tests carried on historic mud bricks (HMBs) and new or modified mud bricks (MMBs) have been discussed. The different characteristics that emerged from the tests on HMBs and MMBs, particularly in terms of physical and mechanical characteristics of the exterior and interior components of bricks have been discussed.

The obtained results show that regular surfaces with uniform components (raw, fill and additive materials) distribution, which are found in MMBs, lead to create an efficient level of adherence among the strengthening systems in the MMBs which increases the resistance to detachment, but also the high values of compressive strength of bricks. Furthermore, mud bricks with weak surfaces and high porosity, such as the vast majority of HMBs, can show a good adherence, but exhibit low number of bonds between its internal components, overall decreasing plasticity and increasing shrinkage and cracking.

However, the results showed that rice straw and homra interact well with the matrix materials of mud bricks to produce a compact mud brick with high degrees of plasticity and low degree of shrinkage. Adding rice straw and fly ash to mud and sand can produce mud brick with suitable bonds among its internal components. Therefore, the use of waste materials is recommended as a good mixture to produce a green and sustainable mud bricks to strengthen historic earthen structures.

Finally, although this experimental study has shown important peculiarities regarding the strengthening of historical mud structures using innovative composite materials, further results and conclusions can be expecting when considering other historic materials, innovative additives or types of experimental tests. As confirmed in this study, it is important to upgrade the actual applied studies on the use of nano and waste-materials in strengthening and repair of historic earthen structures.

\section{ACKNOWLEDGEMENTS}

The author wishes to thank Professor Sayed Taha, Prof. of solids physic Faculty of Science, Fayoum University, for his technical and scientific support during the study phases. 


\section{REFERENCES}

1. Abdelmegeed M., Badogiannis E., Kotsovos G., Vougioukas E. (2014) "Assessment of physical and mechanical properties of historical and traditional masonry buildings: a case study" International journal of conservation science (IJCS) Volume 5, Issue 3, JulySeptember 2014: 343-354

2. Abdelmegeed, M., Hassan, S. (2019) "Diagnostic investigation of decaying limestone in historical buildings at the Mamluks cemetery- city of the dead, Egypt" Egyptian Journal of Archaeological and Restoration Studies "EJARS", Volume 9, Issue 2, December 2019: pp: 183-196

3. Abdelmegeed, M., Kassab M., Shoukry H., \& Taha S. 2019, Innovative Composite Materials for Strengthening Lime-based Mortars in Traditional Masonry Structures, stroitel 'nye materialym construction materials, 2019-773-8-42-47

4. AlAjmi F., Abdalla H., Abdelghaffar M., Almatawah J. 2016, Strength behavior of mud brick in building construction, Open Journal of Civil Engineering, 2016, 6, 482-494.

5. Attia A., 2002, Study of the restoration and conservation of fired bricks historic buildings, applied on one of historical Roman buildings in Tall Elfarma, South Sinai, Master Thesis, restoration Dept, Faculty of archaeology, Cairo University, 2002, $\mathrm{Pp}$ 40: 48.

6. Basta J. 1991, Composition of mud brick in construction of ancient Egyptian antiquities, PhD thesis, Ain-Shams University, 1991, Pp 4-18.

7. Borri, A.; Casadei, P.; Castori, G.; Hammond, J., 2009, Strengthening of brick masonry arches with externally bonded steel reinforced composites. J. Compos. Constr, 2009, 13, 468-475.

8. Borsoi G., Lubelli B., van Hees R., Veiga R., ntónio., 2017" Evaluation of the effectiveness and compatibility of Nanolime consolidants with improved properties" Construction and Building Materials 142 (2017) 385-394.

9. Borsoi G., Tavares M., Veiga R., Santos A. 2012 "Microstructural characterization of consolidant products for historical renders: an innovative nanostructured lime dispersion and a more traditional ethyl silicate limewater solution" Microsc. Microanal. 18 (2012) $1181-1189$.

10.Cameron, C. (1998) "Coursed adobe architecture, style, and social boundaries in the American Southwest" In the archaeology of social boundaries, edited by Stark M., Washington Smithsonian institution press.183-208.

11.Elgar, G. (2008) "The devolution of mud brick: Ethno- archaeology of abandoned earthen dwellings in the Bolivian Andes." Journal of Archaeological Sciences 35: 3057-3071.

12.Elgar, G., Bettencourt N., Conrey R. (2015) "Geochemical characterization of Bolivian formative earthen architecture by Wavelength-Dispersive X-Ray Fluorescence." Geoarchaeology 30 (1): 32-58.

13.El-Gohary M. "The Contrivance of new mud brick for restoring and preserving the Edfa ancient granary-Sohag, Egypt, IJCS, Vol. 3 (2), 2012.

14.El-Gohary, M. (2016) "A holistic approach to the assessment of the groundwater destructive effects on stone decay in Edfu temple using AAS, SEM-EDX and XRD" Environ-Earth. Sci., Vol. 75 (13), pp: 1-11

15.El-Gohary, M., (2010), Investigations of limestone weathering of El-tuba minaret ElMehala, Egypt: a case study, $\boldsymbol{M A} \boldsymbol{A}$, Vol. 10 (1), pp: 61-79

16.El-Kabbany M., 2013, Alternative Building Materials and Components for Affordable Housing in Egypt towards Improved Competitiveness of Modern Earth Construction, Master thesis, Ain Shams University, Faculty of Engineering and University of Stuttgart, Faculty of Architecture and Urban Planning. 2013, Pp. 34;38.

17.Emery V. (2009) "Mud-Brick" In UCLA Encyclopedia of Egyptology, edited by W. Wendrich. Los Angeles: eScholarship, 2009.

18.Fathy H., 1973, Architecture for the Poor, an Experiment in Rural Egypt, Chicago, Illinois: The University of Chicago Press.

- 275 - Modified mud bricks for strengthening historic earthen structures 
19. Fitzner B. (2002) "Damage diagnosis on stone monuments-weathering forms, damage categories and damage indices" in: Viles, H. \& 3Ĝikryl, R., (eds.) Understanding and managing of stone decay, Proc. of the Int. Conf. Stone Weathering and Atmospheric Pollution Network (SWAPNET 2001), Karolinum Press, Charles Univ., Prague, pp: 1156.

20.French, C. 1984. "Sediments analysis of mud brick and natural features at El-Amarna" In Amarna Reports I, edited by B. Kemp, London: Egypt Exploration Society.189-201.

21.Grande E., Imbimbo M. \& Sacco E., 2011, Bond behavior of historical clay bricks strengthened with steel reinforced polymers (SRP), Materials 2011, 4, 585-600.

22.Hansen E., Doehne E., Fidler J., Larson J., Martin B., Matteini M., Sebastian E., Price P., de Tagle A., Teutonico J., Weiss N. 2003 "A review of selected inorganic consolidants and protective treatment for porous calcareous materials" Rev. Conserv. 4 (2003) 13-25.

23.Homsher, R. (2012) "Mud bricks and the process of construction in the Middle Bronze age Southern Levant." Bulletin of the American Schools of Oriental Research 368: 1-27.

24. Ibrahim, M. A., 1987. Community participation in low income housing, s.l.: Ain Shams University.

25.Kevin D. 2015, A field investigation of composite mud brick compressive strength, Master thesis, Department of Mechanical Engineering, Michigan Technological University, $P p$. 1:3.

26. Nodarou E, Frederick C., Hein A. (2008) "Another (mud) brick in the wall: scientific analysis of Bronze Age earthen construction materials from East Crete "Journal of Archaeological Science 35 (2008) 2997-3015.

27. Serena L., (2017) "Field Methods for the Analysis of Mud Brick Architecture" Journal of field archaeology, 2017, Vol. 42, No. 4, 351-363.

28. Warren J., 1999 (Conservation of bricks) first edition, Butterworth Heinemann, London, England, $p p$. 1-6. 